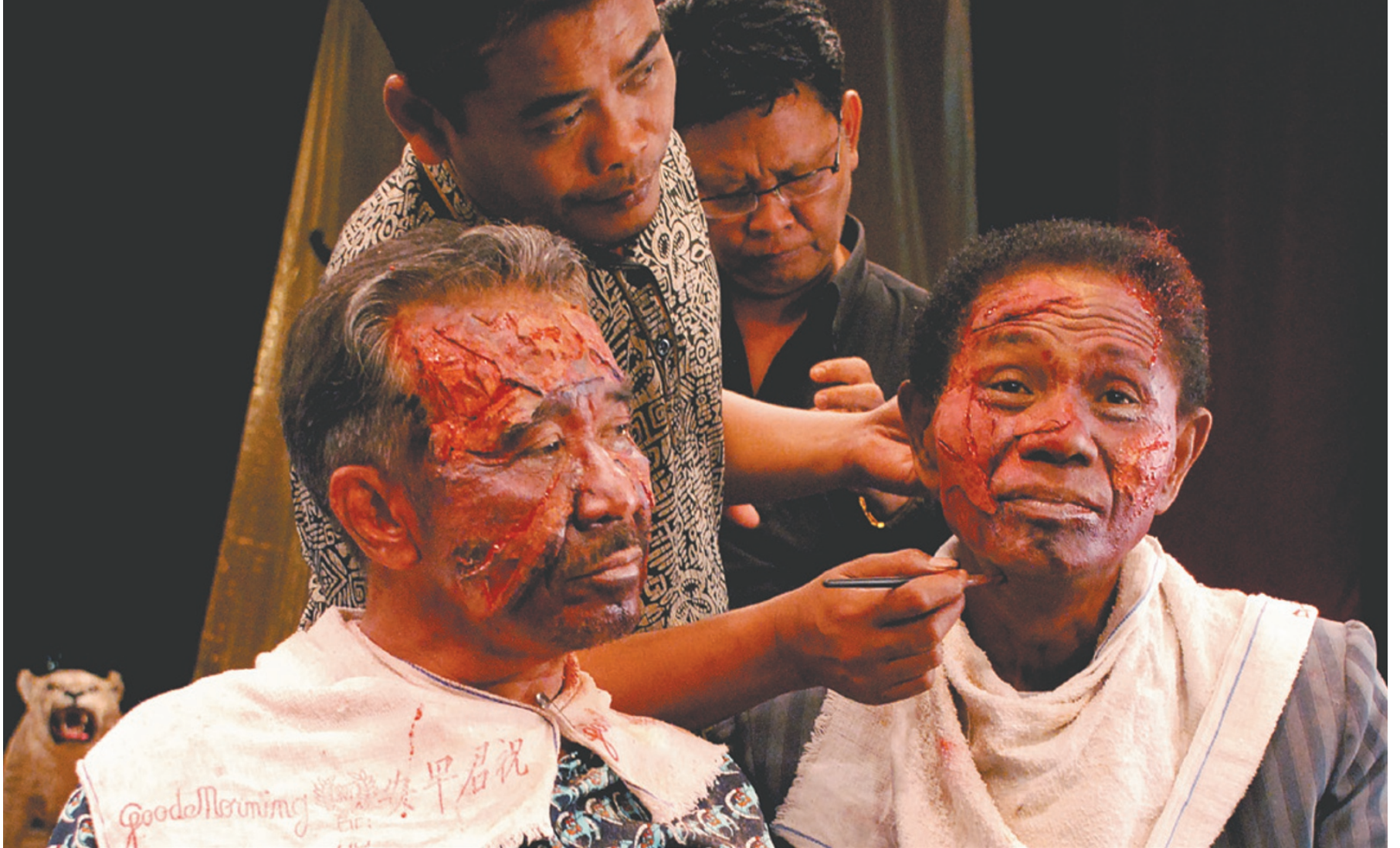

Adi Zulkadry (left) and Anwar Congo, who between them killed hundreds of fellow Indonesians, are made up as their victims in The Act of Killing.

\title{
The science of impunity
}

\section{Tanguy Chouard rates a film probing the psyches of Indonesia's paramilitary killers.}

$\mathrm{I}$ n 1965-66, between half a million and 3 million 'communists' - union mem-

bers, landless farmers, intellectuals and ethnic Chinese people - were exterminated by paramilitary gangsters sponsored by the new military dictatorship of Indonesia. The same regime has been in power and persecuting its opponents ever since.

Twelve years ago, film director Joshua Oppenheimer realized that the killings had received direct support from the West but were hardly ever researched. To him, the situation constituted a living experiment in mass impunity, as if "the Nazis were still in power". Having lost relatives to the Holocaust, he felt he owed it to the victims and their families to document the genocide.

He could not film the survivors without compromising their safety, so Oppenheimer turned to the perpetrators, who boasted about their 'heroic past' (see go.nature.com/2b6v7v). After interviewing more than 40 death-squad leaders, Oppenheimer earned a $\mathrm{PhD}$ in documentary film-making and secured academic funding to explore more deeply how the killers and their government sponsors viewed themselves, and how they wanted to be seen - and feared - by Indonesian society.

He formulated an outlandish anthropology project, turning the camera over to the killers and inviting them to dramatize their story as they wished. The Act of Killing The result is The Act DIRECTED BY JOSHUA of Killing, a fiercely OPPENHEIMER original experiment UKDVD release: in documentary film- 25 November 2013. making that exposes

the entrails of a brutal regime of impunity. The film's diffusion throughout Indonesia is shaking the country's bedrock of violence.

The Act of Killing is "not a movie about the past", Oppenheimer insists; "it is a movie of the imagination". And the perpetrators' imaginations, fuelled by Hollywood gangster movies, emerge as a surreal hotchpotch of crime scenes, involving a cowboy, a drag queen, macaques, elephants and a stuffed crocodile. The grotesque gives way to the disturbing, and bright colours fade to darkness, in a chilling crescendo of realism. At the film's centre are the persistent nightmares of Anwar Congo, a man believed to have executed about 1,000 people.

After impersonating a victim, the smartly dressed, often avuncular Congo briefly empathizes with those whom he tortured. But in one of the most terrifying scenes, he suddenly pulls out his knife and lacerates a teddy bear, a stand-in for the baby of a 'communist' under interrogation, declaring: "this is what we do to those who bribe us with their children."
Fellow executioner Adi Zulkadry is remorseless. "It's all about finding the right excuse," he lectures, as fake blood is plastered onto his face. When Oppenheimer confronts him about the Geneva Conventions, Zulkadry retorts: "War crimes are defined by the winners. I'm a winner, so I can make my own definition." Zulkadry is more lucid than his fellow film-makers about the consequences of exposing truth. "For me, reopening this case is a provocation to fight," he warns.

Aware that a public banning of the film would justify official violence against anyone seeing it, Oppenheimer first gave private screenings to Indonesian journalists, celebrities and human-rights activists. Huge media coverage ensued and the film, now freely downloadable, has been seen by more than 200,000 Indonesians, he says.

Oppenheimer's freakish project allowed him to navigate the murky waters of Indonesia's 'democracy' and then to jolt its collective conscience into ending 47 years of media silence. Impunity, in retrospect, was a metastable state - a regime that most knew was wrong, but that no one could fully expose without a powerful catalyst. .

Tanguy Chouard is a senior biology editor at Nature. 